\title{
Trophic state assessment in two gravel pits (El Campillo \& El Porcal) using airborne imagery
}

\author{
José Antonio Domínguez Gómez ${ }^{1}$ and Ramón Peña ${ }^{2}$ \\ 1. Universidad de Alcalá. de Henares, C/ Colegios n 2, 28001 ALCALÁ DE HENARES \\ 2. Centro de Estudios Hidrogr.ficos del CEDEX, Paseo Bajo de la Virgen del Puerto, 3, 28005 MADRID
}

\begin{abstract}
The area between low Rivers Manzanares and Jarama, (South of Madrid), was designated as a nature reserve in 1994. The continued gravel and sand-extracting activity has generated many gravel pits, a new peculiar ecosystem with very diverse biotopes which must be protected and restored. During recent years, the University of Alcalá de Henares has assessed the environmental impact derived from the extraction of dry materials in this area. Since 1988, the CEDEX carried out a limnological survey of main water bodies on the river Tajo and near by basins, using Landsat TM imagery, as well as of inland water quality using airborne sensor imagery. In 1997, the CEDEX and the University of Alcalá de henares studied the trophic state in gravel pits El Campillo and El Porcal by using ATM imagery. Multiple regression equations, of suspended solids and chlorophyll $a$ on transparency, yielded good determination coefficients $\left(\mathrm{r}^{2}\right)$. Four thematic maps were obtained for each water body, showing spatial variability of eutrophy along ponds, laid on geomorphological data. Trophic state in both ponds was generally eutrophic with mesotrophic patches. Use of airborne imagery (ATM) can solve problems of Landsat sensor in terms of resolution and work schedule, because ATM resolution is higher and election of flight time permits cloud cover to be avoided. Use of ATM sensors allowed an accurate cartography of limnological parameters of gravel pits in El Campillo and El Porcal.
\end{abstract}

Key words: Water quality, eutrophication, airborne remote sensing, gravel pits.

\section{RESUMEN}

La zona situada entre los ríos del bajo Manzanares y el Jarama, al Sur de Madrid, fue declarada en 1994 reserva de la naturaleza. La continuada actividad de extracción de grava y arena ha creado muchas lagunas de gravera, un nuevo y peculiar ecosistema con biotopos muy diversificados que deben ser protegidos y restaurados. Durante los últimos años, la Universidad de Alcalá de Henares ha realizado diversos estudios para establecer el impacto ecológico derivado de la extracción de áridos en esta zona. Desde 1988, el CEDEX ha realizado un reconocimiento mediante sensores remotos de las principales masas de agua del río Tajo y otras cuencas, usando imágenes TM Landsat, así como diversos estudios sobre la calidad del agua utilizando sensores de imagen aerotransportados. En 1997, el CEDEX y la Universidad de Alcalá de Henares estudiaron el estado trófico de las lagunas de gravera de El Campillo y El Porcal usando imágenes ATM. Las ecuaciones de regresión múltiple, correspondientes a los sólidos en suspensión, clorofila a y transparencia, dan un buen coeficiente de determinación ( $\left.r^{2}\right)$. A partir de los cuatro mapas temáticos obtenidos para cada una de las masas de agua mostrando la variabilidad espacial a lo largo de cada una, en concordancia con sus cambios geomorfológicos, el estado trófico en ambas lagunas puede ser considerado eutrófico con algunas zonas mesotróficas. El uso de imágenes de sensores aerotransportados puede resolver los problemas de los sensores del Landsat en términos de resolución y programa de trabajo, ya que la sensibilidad de los sensores es mayor y la posibilidad de escoger el momento del vuelo permite evitar el efecto de las nubes. En este caso, el uso del sensor ATM permitió realizar una cartografía temática detallada similar a la que podía ser obtenida en los estudios limnológicos en las lagunas de gravera del El Campillo y El Porcal.

Palabras clave: Calidad del agua. Eutrofización, Sensor remoto aerotransportado, lagunas de gravera.

Limnetica 16: 107-112 (1999)

(C) Asociación Española de Limnología, Madrid. Spain. ISSN: 0213-8409. 


\section{INTRODUCTION}

The area between low Rivers Manzanares and Jarama, South of Madrid (Fig. 1), were designated as a natural park in 1994 (Official Bulletin of Madrid, BOCM 163, July $12^{\text {th }}$, 1994). Usually known as Southeast Park, its main purpose is to protect this area against all kind of environmental impact. The largest impact is intense gravel extraction activity. Designation of the area as protected park has finally lead to prohibition of gravel extraction. Multiple works have studied the possibilities of restoring this area.

There were four main types of extractive activity in Southeast Park:

a. Hillside quarries for the eventual extraction of gypsum, usually in small fragments.

b. Hillside quarries for the extraction of several types and sizes of dry materials.

c. Gravel beds above groundwater level.

d. Gravel beds below groundwater level. These are usually extensive areas, larger than 10 hectares and less than 10-metre deep. Here groundwater springs up trough gravel beds.

Ponds, thus created, are new, peculiar ecosystems with very diverse biotopes. Recent legislation (law 6/1994, June 28 ${ }^{\text {th }}$ ) has been passed which regulates protection, restoration and management of the park.

Choice of ponds for this study was based both on location within the park and level of extracting activity. Pond "El Campillo" is in River Jarama valley, before junction with River Manzanares, very near the town of RivasVaciamadrid. At present, there is no gravel extraction. Pond "El Porcal" is located downstream of Rivas -Vaciamadrid town, near San Martín de la Vega and downstream of the junction of Rivers Manzanares and Jarama. This pond is still subject to important extracting activity.

During recent years, the University of Alcalá de Henares has completed its work on the environmental impact assessment of extracting activities. CEDEX carried out first limnological surveys of several water bodies in the River Tajo basin, making use of Landsat TM imagery. This experience was extended to a variety of subsequent studies (Peña, 1991, Peña \& Serrano, 1992, 1994, Serrano \& Peña, 1997). Experiences were then joined in the present proposal for the assessment of the trophic state gravel pits El Campillo, El Porcal and Las Madres in 1992, by means of Landsat TM imagery (Domínguez et al., 1997). The TM sensor was not resolute enough for small water bodies. Thus, CEDEX and INTA agreed to use the sensor Daedalus 1268 (ATM), with a spatial resolution of $3.5 \mathrm{~m}$ at the nadir. Flight, and data collection, took off on October $29^{\text {th }} 1997$.

\section{MATERIAL AND METHODOLOGY}

Area to cover was defined on a 1:50000 map of the region of Madrid. We wanted to restrict data collection to one single flight. This was to minimize difficulties derived from the vicinity of air traffic access routes to Barajas Airport (Madrid). In addition weather conditions were unstable in the previous days to flying, with low clouds and a high change of rain.

Simultaneously to the acquisition of aerial images on-site "ground truthing" data was collected on chlorophyll $a$, suspended solids, Secchi depth and surface water temperature.

The sensor used (i.e. DAEDALUS 1268) could separate radiation reflected from the water surface into eleven spectral bands, ranging from blue to thermal infrared wavelengths. The sensor was adjusted and callibrated in a specially-designed data bank at the Remote Sensing Laboratory of INTA. Digital images were transformed to ELAS format on a compatible magnetic support applying a specific conversion program . A panoramic correction was then applied by means of an algorithm, developed by INTA according to the geometric distortions derived from airborne acquisition conditions (Peña et al., 1997).

Imagery provided by the INTA to CEDEX was both radiometric and geometrically corrected by use of a Geographical Information System (GIS) and a remote sensing package (i.e. PCI 6.0). Study areas were first selected. Digital levels in 
all bands (i.e. Digital Numbers, ND) were then extracted of sampling points.

Multiple "stepwise" regressions by selective iteration, adding or removing variables (Verdin, 1984, Peña, 1991) related parameter values with digital numbers (i.e. "ND" or radiometric values) for the sampling points. Secchi disk transparency, suspended solids and the chlorophyll $a$ were the dependent variables in this analysis. The values of ATM2, ATM3, ATM5, ATM7 and ATM9, corresponding to the spectral ranges of Landsat 5 bands TM1, TM2, TM3, TM4 and TM5 respectively, were the independent variables.

Thermal imagery (bands ATM11, ATM12) used two black bodies (emissivity > 0.99) for cold and warm reference (i.e. for $5^{\circ}$ and $45^{\circ} \mathrm{C}$ ), to assing real temperatures to radiometric values for each line of image. This approach provided the conversion of values given by the sensor to temperature $\left({ }^{\circ} \mathrm{C}\right)$. Temperature $(\mathrm{t})$ was related to digital values (i.e.ND) by linear regression, according to the following equation,

$$
\mathrm{t}=\mathrm{m} * \mathrm{ND}+\mathrm{n}
$$

where " $\mathrm{m}$ " and " $\mathrm{n}$ " are constants.

Calculated values are apparent ambient temperatures, ignoring atmospheric interference and ground emissivity. In case $m=0.18$, representing thermal resolution in the absence of instrumental noise. The value " $\mathrm{n}$ " is the y-intercept (Peña et al., 1997).

\section{RESULTS AND DISCUSSION}

Four thematic maps were obtained for each water body. See location map of gravel pits "El Campillo" and "El Porcal" in figure 1. Spatial patterns within ponds follow geomorphological changes and intensity of extraction activity (Figs. 2 and 3).

Figure 2 (i.e. "El Campillo") shows spatial changes in suspended solids concentration $\left(\mathrm{mg} \cdot \mathrm{L}^{-1}\right)$ against depth changes. Suspended solids, Secchi depth and chlorophyll- $a$ concentration show a gradient of increasing concentration from west to east. Maximum values are attained in shallower areas with rich macrophyte growth. Temperature maps did not show clear patterns.

Spatial distribution of suspended solids and transparency (i.e. secchi depth) were related to depth and extracting activity areas (figure 3, "El Porcal"). Temperature indicated a moderate gradient towards shallower areas, with patches corresponding to extraction areas.

Regression equations of suspended solids, chlorophyll $a$ and transparency against and determination coefficients $\left(\mathrm{r}^{2}\right)$ as well as the temperature equation obtained are shown in Table 1 (El Campillo) and Table 2 (El Porcal).

\section{CONCLUSIONS}

The use of satellite imagery for the trophic state assessment of small water bodies has several limitations, namely, spatial and temporal resolution and atmospheric conditions. Airborne imagery can solve these problems because of higher resolution of sensors and the possibility of choosing flight time to avoid days with excessive cloud cover.

In the present study the use of an ATM sensor allowed to obtain an accurate thematic cartography of limnological parameters in gravel pits El Campillo and El Porcal (Madrid, Spain).

Trophic state of these water bodies, at least at the time of image capture, can be classified as eutrophic, with mesotrophic patches.

\section{REFERENCES}

DOMÍNGUEZ, J.A., A. SASTRE Y R. PEÑA 1997. Detección de cambios en los humedales del río Jarama entre 1988 y 1992 y evaluación de estado trófico de las lagunas del Campillo, el Porcal y las Madres en 1992 mediante imágenes Landsat TM. In: Teledetección aplicada a la gestión de recursos naturales y medio litoral marino, C. Hernández \& J.E. Arias (eds.): 339-351, Santiago de Compostela. PEÑA, R. 1991. Proceso de imagenes para teledetección por satélite Landsat en embalses españoles. Jornadas sobre eutrofización de embalses e indicadores biológicos de la calidad de las aguas de los ríos: 107-135, CEDEX, Madrid. 
PEÑA, R. Y M. L. SERRANO 1992. Evaluación del estado trófico de los embalses mediante imágenes digitales. Ingeniería Civil, 86: 37- 44.

PEÑA, R. Y M. L. SERRANO 1994. Seguimiento del estado trófico de los embalses del alto Tajo por teledetección. Limnetica, 10(1): 69-81.

PEÑA, R., A. FERNÁNDEZ-RENAU, E. DE MIGUEL, J. A. GÓMEZ, M. L. SERRANO Y A. RUIZ-VERDÚ 1997. Utilización de sensores aeroportados en aplicaciones de calidad del agua: Evaluación de vertidos térmicos en el río Tajo y difusión de sedimentos en los ríos Esera y Cinca. In: Teledetección aplicada a la gestión de recursos naturales y medio litoral marino. C. Hernández \& J.E. Arias (eds.): 335-338, Santiago de Compostela. SERRANO, M.L. \& R. PEÑA 1997. Evolución del estado trófico de tres embalses del Júcar por teledetección. In: Teledetección Usos y Aplicaciones. J.L. Casanova \& J.Sanz Justo (eds.): 223-229. Valladolid. VERDIN, J.P., 1984. Limnological applications of multi-spectral remote sensing, USBR Report No. REC-ERC-85-2. 51pp.

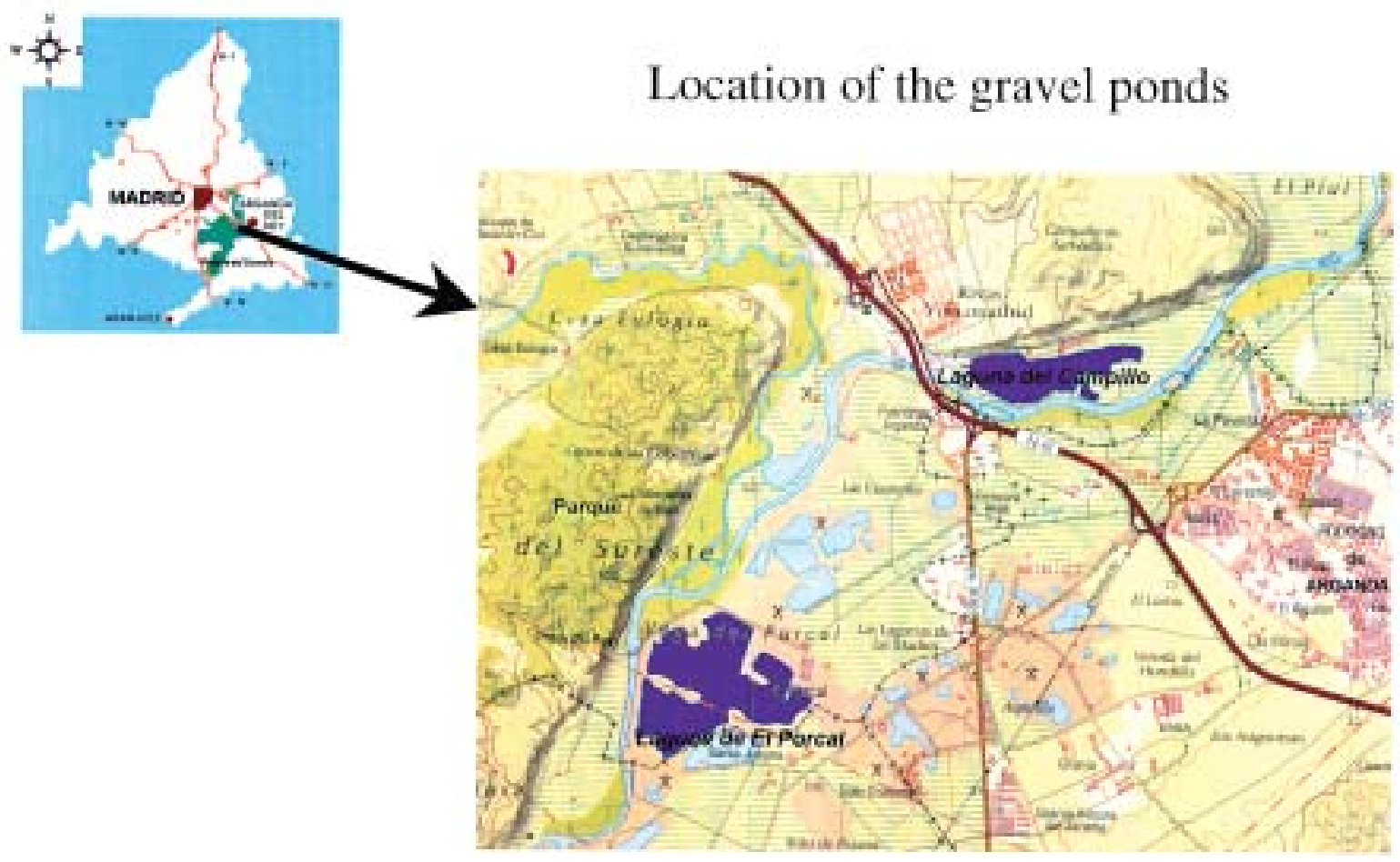

Figure 1. Location map of gravel pits El Campillo and El Porcal. Ubicación cartográfica de las lagunas de gravera de El Porcal y El Campillo. 
क्षे

\section{EL CAMPILLO POND (29.10.1997)}

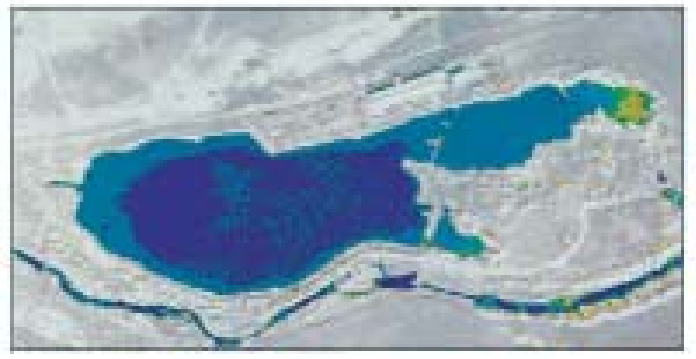

Suspended solids $(\mathrm{mg} / \mathrm{l})$

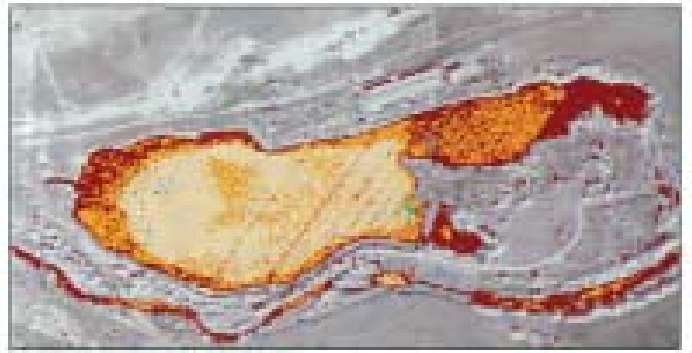

Transparency (m)

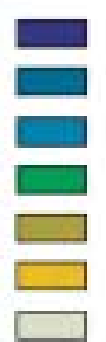

$0-10$

$10-20$

$20-30$

$30=40$

$40-50$

$50-60$

$60-70$

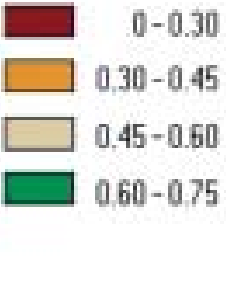

$0.30-0.45$

$.45-0.60$

$-0.75$
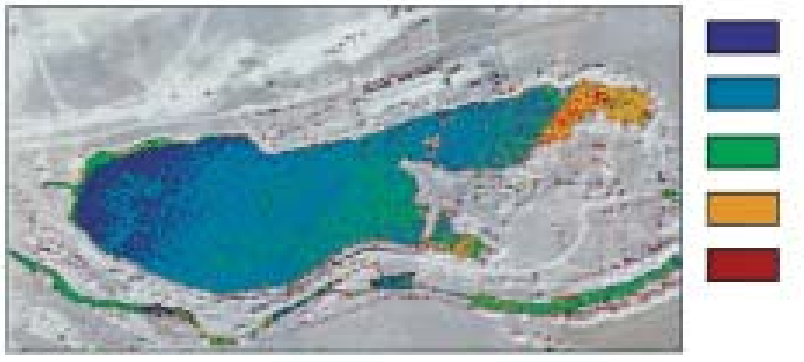

Chlorophyll a $\left(\mathrm{mg} / \mathrm{m}^{3}\right)$
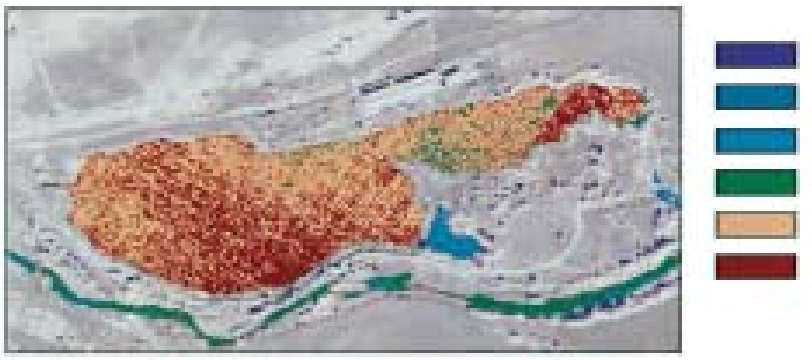

$14-15$

$16-16$

$16.5-17$

$17.0-17$.

$17.5-17$

$17.6-18$

Temperature (" $\mathrm{C})$

Figure 2. Thematic maps of gravel pit El Campillo, showing the spatial distribution of suspended solids, chlorophyll $a$, transparency and temperature. Mapas temáticos de la laguna de gravera de El Campillo, mostrando la distribución espacial de los sólidos en suspensión, clorofila a, transparencia y temperatura. 


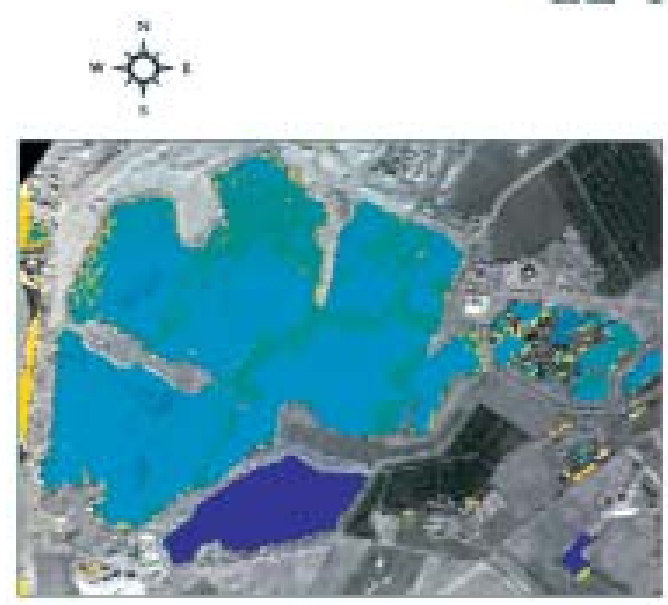

Suspended Solids (mg/)

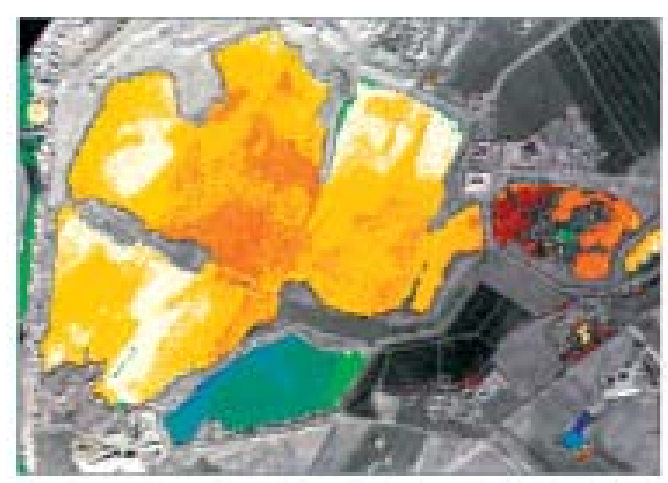

Transparency (m)
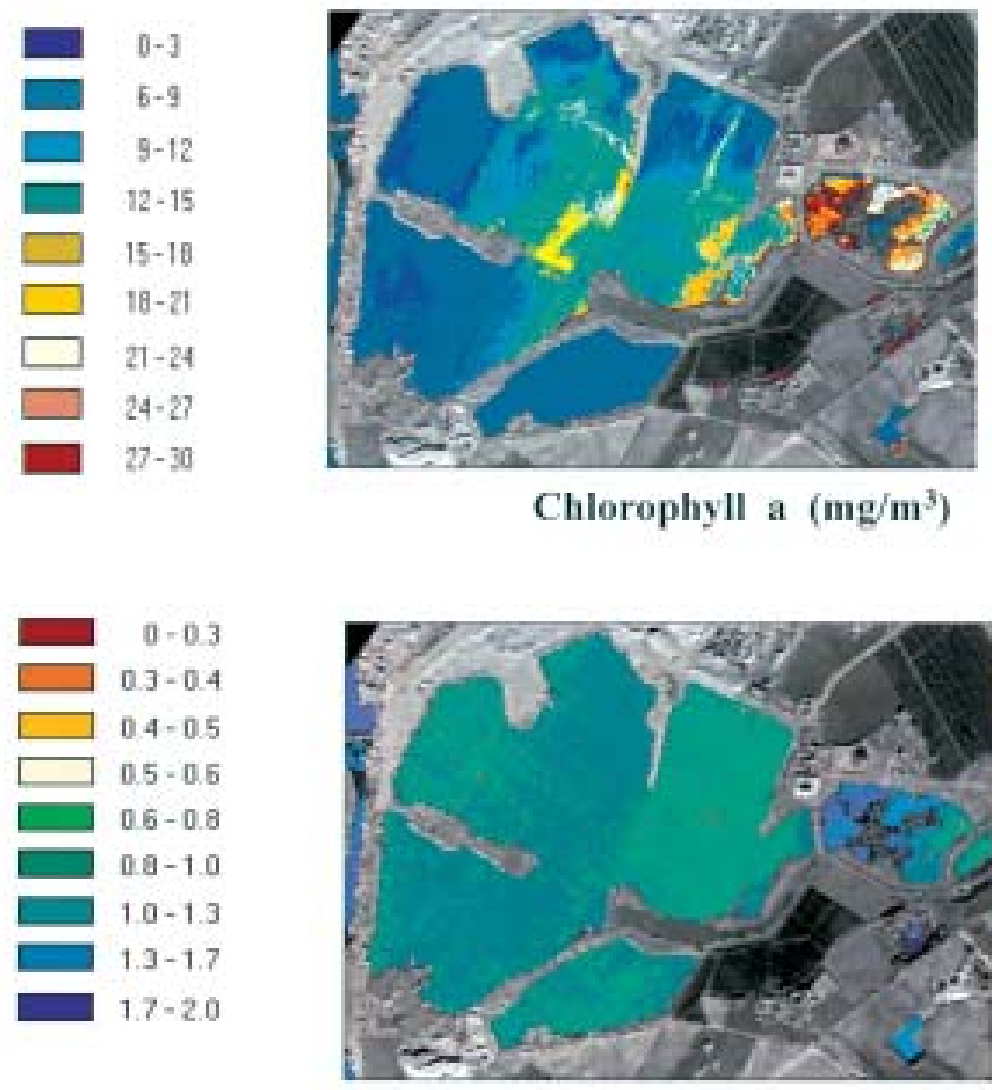

Temperature $\left({ }^{\circ} \mathrm{C}\right)$

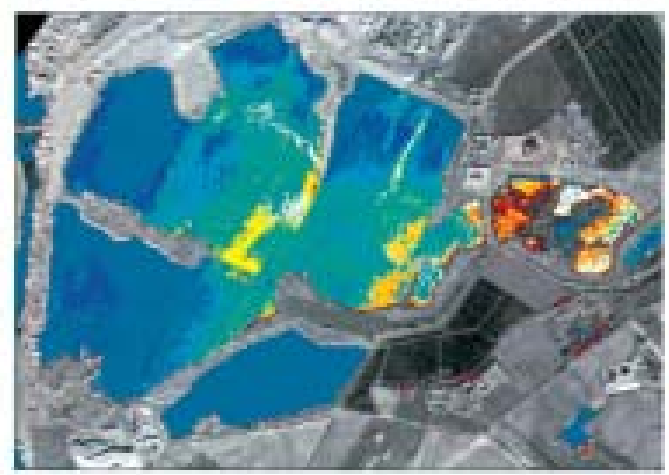

Chlorophyll a $\left(\mathrm{mg} / \mathrm{m}^{3}\right)$

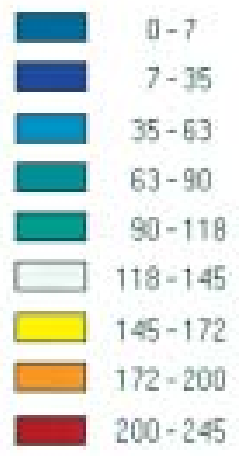

$200-245$

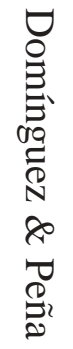

$17.4-17.5$

$17.5-17.7$

$177-18.0$ $\sin a$

Figure 3. Thematic maps of gravel pit El Porcal, showing the spatial distribution of suspended solids, chlorophyll a, transparency and temperature. Mapas temáticos de la laguna de gravera de El Porcal, mostrando la distribución espacial de sólidos en suspensión, clorofila a, transparencia y temperatura. 